\title{
The Effect of Metacognitive Instruction on L2 Learners' Listening Abilities and Beliefs about Listening
}

\author{
Karim Shabani \\ Allameh Mohaddes Nouri University, Nour, Iran \\ E-mail: shabanikarim@gmail.com \\ Mahsa Heidarian (corresponding author) \\ Allameh Mohaddes Nouri University, Nour, Iran \\ E-mail: Mahsaa.heidarian@yahoo.com
}

Received: June 28, 2015 Accepted: July 14, 2015 Published: July 20, 2015

doi:10.5296/jet.v2i2.8033 URL: http://dx.doi.org/10.5296/jet.v2i2.8033

\begin{abstract}
Framed in metacognition and sociocultural theory, the present study aims at probing the effect of metacognitive instruction on the learners' perceptions about listening in one hand, and examining whether this pedagogical sequence of teaching listening may lead to the learners' listening development in the course of one semester on the other. To gather desirable data, 90 (50 males and 40 females) young Iranian EFL (English as a foreign language) learners, who were studying English in a private language institute, were the potential participants of the study. Data was gathered through semi-structured interview, open-ended questionnaire, as well as KET (Key English Test) listening test. Findings highlighted the occurrence of changes in the learners' beliefs about listening at the end of the term after they received metacognitive listening instruction. Similarly, quantitative data analysis of the pre-and post-test indicated that the participants in the experimental group outperformed those of the control group. Results revealed that metacognitive listening instruction seems to be more beneficial for less-skilled (novice) listeners to take advantage of a process-based listening instruction to improve their listening abilities.
\end{abstract}

Keywords: listening development, learners' beliefs, metacognitive listening instruction, young learners

\section{Introduction}

Listening has been conceived as an important skill among the four major skills. However, the problem exists in how teachers should deal with teaching listening in the classroom environment to create an opportunity for learners to improve their listening skill. Recent studies focused either on product or process-based teaching in listening. Two approaches impose some 
problems on both teachers and learners. In the case of product-based view of listening, there is a sense of anxiety among the learners (Elkhafaifi, 2005) in that they are expected to provide the right answer to the test. On the other hand, process-based view of listening involves all the processes in comprehending a listening exercise and how learners elaborate on what is being listened and how their mind is going to parse it. The most recent view toward teaching listening is to seek an integration of the two approaches. The mentioned problem seems to be solved by metacognitive instruction, in which learners go through both product and process-based listening, and engage in the process of listening more consciously and practically rather than focusing on one part at the cost of losing the other. Vandergrift (2007) argues that listeners need to be aware of the cognitive processing underlying listening and this sort of awareness lies in the integration of bottom-up and top-down processes considered as a pedagogical sequence in which listeners benefit from both contextual and segmental requirements depending on the purpose of the listening. It is helpful for understanding how different types of knowledge interact in parallel fashion as listeners create a mental representation of what they have heard. Table 1 outlines a task- based, pedagogical sequence that leads listeners through the processes involved in real-life listening, developing both the top-down and bottom-up dimensions of listening as well as metacognitive awareness of the cognitive processes underlying listening (see Vandergrift, 2004). It is of value to note that the present study follows this process-based framework for listening instruction to enhance the learners' development in their beliefs and listening abilities.

In fact, metacognitive listening has been investigated by a number of researchers (e.g. Goh \& Tiab, 2006; Vandergrift, 2004) to emphasize its significance in teaching listening, however, there are some unresolved issues that need to be considered in future studies as proposed by past researchers.

Studies conducted in the area of listening instruction deal with shortages of research carried out in this field and specifically metacognitive listening. It should be noted that most of these studies were done in an ESL (English as a second language) context or universities while the present study is to figure out how this strategy instruction may be effective in the foreign context and classroom environment to fulfill the learners' listening requirement.

More importantly, learners' beliefs about listening have not yet been considered by researchers. Studies done regarding learners' beliefs were mostly concerned with beliefs about language learning (Kern, 1995; Horwitz, 1988); however, the present study looks into the learners' evolution of their beliefs about listening as a result of taking part in strategy instruction practice. It should be noted that belief changes are justified within the framework of sociocultural theory in which the notions of mediation and regulation (or self-regulation) are practical. Mediation is the central concept of sociocultural theory. Vygotsky's fundamental claim is that higher forms of human mental activity are mediated by culturally constructed auxiliary means (Lantolf \& Throne, 2006). According to Lantolf (2004), regulation is made when learning occurs in a supportive manner (other-regulation) and then continues individually (self-regulation).

Finally, there exist shortages of studies on the application of metaconitive listening on young 
learners. Researchers focused much on the effectiveness of this strategy on adult learners (Birjandi \& Rahimi, 2012; Rasouli, Mollakhan, \& Karbalaei, 2013) remaining this gap that more research is required to examine whether it has any possible impact on young learners and especially in the institute context as the present research is to fill it.

Table 1. Pedagogical sequence for teaching 12 listening (Vandergrift, 2004)

\begin{tabular}{|l|l|}
\hline \multicolumn{1}{|c|}{ Pedagogical stages } & Metacognitive processes \\
\hline $\begin{array}{l}\text { 1. Pre-listening-Planning/predicting stage: } \\
\text { After learners have been informed of the topic and text type, } \\
\text { they predict the types of information and possible words they } \\
\text { may hear. }\end{array}$ & 1 Planning \\
\hline $\begin{array}{l}\text { 2. First listen-First verification stage: } \\
\text { a. Learners verify their initial hypotheses, correct as required, } \\
\text { and note additional information understood. } \\
\text { b. Learners compare what they have understood/written with } \\
\text { a partner, modify as required, establish what still needs } \\
\text { resolution, and decide on the important details that still } \\
\text { require special attention. }\end{array}$ & $\begin{array}{l}\text { 2bonitoring, evaluation, } \\
\text { and planning }\end{array}$ \\
\hline $\begin{array}{l}\text { 3. Second listen-Second verification stage: } \\
\text { a. Learners verify points of earlier disagreement, make } \\
\text { corrections, and write down additional details understood. } \\
\text { b. Class discussion in which all class members contribute to } \\
\text { the reconstruction of the text's main points and most pertinent } \\
\text { details, interspersed with reflections on how learners arrived } \\
\text { at the meaning of certain words or parts of the text. }\end{array}$ & $\begin{array}{l}\text { 3a. Monitoring, evaluation, } \\
\text { and problem-solving } \\
\text { and problem-solving }\end{array}$ \\
\hline $\begin{array}{l}\text { 4. Third listen-Final verification stage: } \\
\text { Learners listen specifically for the information revealed in the } \\
\text { class discussion which they were not able to make out earlier. } \\
\text { This listen may also be accompanied by the transcript of all or } \\
\text { part of the text. }\end{array}$ & \begin{tabular}{l} 
problem-solving \\
\hline $\begin{array}{l}\text { 5. Reflection and goal-setting stage: } \\
\text { Based on the earlier discussion of strategies used to } \\
\text { compensate for what was not understood, learners write goals } \\
\text { for the next listening activity. }\end{array}$
\end{tabular} \\
\hline
\end{tabular}

\section{Research Questions}

The study, therefore, seeks answer to the following questions:

1) To what extent can metacognitive listening instruction change the learners' beliefs about teaching listening? 
2) Does the experimental group receiving the metacognitive instruction outperform the control group?

3) Do the less-skilled listeners in the experimental group show greater improvement than the more-skilled group in listening comprehension?

\section{Methodology}

\subsection{Participants}

In order to select the desirable participants, Dornyei (2007) argues that the sampling process is difficult since researchers seek subjects who can provide them with rich data to be able to thoroughly answer the research questions. Therefore, the issue of sampling can be proposed in that how researchers can choose those participants that go in line with the purpose of the study. As to the participants of the study, participants were selected using convenience sampling procedure as Mackay and Gass (2005) explain that researcher can benefit from those participants who are available and at the same time can assist the researchers to fulfill the purpose of the study.

Regarding the purpose of the study, 90 young learners who studied English in a private language institute at Kish Air Cultural Institute were the potential candidates for the present study to examine the effectiveness of metacognitive listening instruction on their development and on their perceptions about listening as well. They range in age from 14 to 18 years old. The participants include 50 males and 40 females studying English for at least two years. As to the purpose of the study, 52 students were assigned to experimental group receiving treatment in the form of metacognitive listening instruction, and the remaining 38 students were selected as the control group receiving no instruction.

\subsection{Instrumentation}

The current study conducted semi-structured interview to get to uncover the participants' beliefs about listening before and after the term. The learners also answered an open-ended questionnaire to explore more accurate information regarding the participants' beliefs about listening. Participants also listened to KET (Key English Test, Cambridge University Press) (see appendix 1) material to look into their listening performance before and after treatment sessions.

\subsection{Procedure}

As to the sociocultural framework in studying beliefs, it typically employs the qualitative research methods as Bernat (2008) expresses that studies within this perspective are usually small-scale and use in-depth descriptive and interpretive analysis. Thus, the present study benefits from the qualitative and interpretative methodology to investigate the complex and dynamic nature of learners' beliefs about teaching listening.

To precisely grasp the complex nature of beliefs about listening, learners were invited to answer an open-ended questionnaire (before and after the treatment session) to freely express their thoughts about teaching listening. In order to verify what they wrote in their questionnaires, the participants were kindly requested to take part in a semi-structured 
interview. It was aimed to assure what they wrote in the questionnaire was, to large extent, in line with their interview data. In fact, both open-ended questionnaire and semi-structure interview were adopted to track changes in the learners' beliefs about teaching listening as a result of being exposed to an instruction in metacognitive listening.

On the other hand, the quantitative aspect of the study seeks to explore whether application of metacognition in listening can improve the learners' listening performance. In this regard, prior to the treatment, both experimental and control groups took the pre-test (KET listening test) to gather their initial listening performance. As to the metacognitive instruction, the experimental group underwent the treatment procedure in five sessions based on the pedagogical sequence proposed by Vandergrift (2004), in which they received metacognitive listening instruction through the following stages:

1) Planning and predicting: the planning phase prepares listeners to be proactive in their listening efforts. Proactive listeners decide what to listen for and establish the necessary conditions for successful listening, in order to pay close attention to meaning while listening.

2) Verification of their hypothesis based on their prior knowledge about the topic after first listening: while listening to the text, listeners monitor their comprehension in light of their predictions and make adjustments, as necessary.

3) Group or peer work to reach agreement or disagreement based on the initial hypothesis: here listeners get ready to listen to the recording for the second time, and they try to guess whether new information can be added to the previously-mentioned opinions with group work or class discussions guided by the teacher.

4) Class discussion for better understanding of the points of agreement and disagreement after the second listening stage: after the second listen, learners begin by revising and adding new information to their notes, as required.

5) Third listening stage aiming at assisting the learners to go through the details of the recording: the final verification stage begins with a third listen to the text. This allows learners to listen for information revealed during discussion that they may not have understood earlier.

6) Finally, learners reflect upon their activity in terms of their understanding of the content and determine their goals for the next listening activity: during the last step of this listening activity, the teacher encourages learners to evaluate their approach to the activity, the difficulties they confronted, and how they were or were not successful in coping with these difficulties.

After the treatment, the participants were given another version of KET listening test as the post-test to look into the effectiveness of metacognitive listening treatment on their listening performance. 


\subsection{Data Collection and Analysis}

Learners' beliefs about listening were gathered through semi-structured interview and open-ended questionnaire before and after the treatment session. First, the participants responded to the questionnaire, and then were invited to take part in the interview session. In fact, it is worth noting that 30 participants (of experimental group) and 15 participants (of the control group) were randomly selected to respond to the questionnaire and take part in the interview. The questions they answered are as follows:

1) What do you know about listening?

2) How should listening be taught?

3) Are you interested in learning to listen?

4) How teaching and learning listening are important to you?

It should be noted that semi-structured interview was conducted almost with the same questions to check consistency among the learners' answers.

In order to analyze the first research question i.e. 'to what extent can metacognitive listening instruction change the learners' beliefs about teaching listening', learners' partial transcription of their interview session as well as grounded theory methodology (Glaser \& Strauss, 1967) were provided to be aware of their beliefs. As to the transcription of data, Dornyei (2007) states that researchers can benefit from partial transcription i.e. the transcription of the parts that are significant to the study. In this regard, those selected extracts of the interview data, which were in alignment with the main categories gained from grounded theory methodology, were provided to highlight the sort of beliefs learners had about listening during the term. As to the significance of the grounded theory, Dornyei (2007) adds this point that it is a qualitative research method which involves the detailed procedural guidelines for data analysis providing an in-depth analysis of a phenomenon. In fact, grounded theory is in favor of coding data regarding the learners' perceptions about listening. For this purpose, three stages were defined according to Dornyei (2007) including:

1) Open coding of diaries in which the textual data is broken to chunks. Each of these segments is assigned a category.

2) Axial coding of the data that the researcher makes connections between the categories of diaries segments found in the first step to create a meaningful set of categories.

3) Selective coding by which the researcher aims to elaborate on an idea that has already been specified in the second stage.

Concerning the learners' responses to the questionnaire, coding of the answers were conducted to find out the categories emerged according to the initial coding of the answers. Based on the initial coding of the answers, axial coding of data was carried out to discover the main categories of data for the purpose of selective coding at the final stage. These categories involved 1) learners' beliefs about listening at the beginning of the term; and 2) learners' beliefs about listening at the end of the term. Each of these two main categories has sub-categories to appropriately analyze the data. Regarding the first category, the following classifications can be made as to the coding procedure: 
a) Listening is difficult to learn

b) Lack of interest in Listening

As to the learners' beliefs about the listening at the end of the term, the following codes emerged:

c) Listening can be taken at the service of speaking

d) Listening is more important than the other skills

In order to answer the second and third research questions i.e. 'does the experimental group receiving the metacognitive instruction outperform the control group, and do the less-skilled listeners (i.e., those whose listening grade was below the overall mean score) in the experimental group show greater improvement in listening comprehension', an Independent Sample T-Test was applied to statistically analyzed the pre-and post-test of the study using SPSS software (version 18.00).

\section{Results}

In order to answer the first research question, learners' responses to the questionnaire were categorized following the coding of data, and then partial transcriptions of the semi-structured interviews were provided to be in line with the categories. Concerning the learners' responses to the questionnaire, coding of the answers were conducted to find out the categories emerged according to the initial coding of the answers. Based on the initial coding of the answers, axial coding of data was carried out to discover the main categories of data for the purpose of selective coding at the final stage. These categories involved 1) learners' beliefs about listening at the beginning of the term; and 2) learners' beliefs about listening at the end of the term. Each of these two main categories has sub-categories to appropriately analyze the data. Regarding the first category, the following classifications can be made as to the coding procedure:

a) Listening is difficult to learn

b) Lack of interest in Listening

As to the learners' beliefs about the listening at the end of the term, the following codes emerged:

c) Listening can be taken at the service of speaking

d) Listening is more important than the other skills

Additionally, it is worth noting that 30 participants (of experimental group) and 15 participants (of the control group) were randomly selected to respond to the questionnaire and take part in the interview. As the responses of the experimental group are of importance based on the purpose of the study, their belief change was thoroughly analyzed. Here, each of these sub-categories is discussed and interview extracts are provided as well.

\subsection{Learners' Beliefs about Listening at the Beginning of the Term}

As to the learners' beliefs about listening, their responses to the questionnaire indicated that their beliefs seemed to be raw and to a large extent simplistic, which clearly highlights their 
unfamiliarity with this important skill. In the following, learners' sub-categories and interview extracts are provided to acknowledge the learners' lack of awareness about listening at the beginning of the term.

\subsubsection{Listening is Difficult to Learn}

Regarding the difficulty of the listening, almost all the participants $(n=29)$ believed that learning to listen is not as easy as the other skills such as speaking. In fact, the learners' seemed to have not sufficient understanding of the listening skill and how it can be taught as effectively as possible to make it seem less difficult for them. Here, it was found that learners were afraid of listening exercises and they always face difficulty in understanding the main points or maybe vocabularies of a listening task. As an example, one of the participants' extracts is as follows:

Extract 1 .

"I believe that listening is the most difficult skill since it does not have any variety and therefore less energetic and full of hard vocabularies. Listening activities do not help us to be better in listening."

It seems that the learner was not satisfied with listening activities done in the class and explains it as boring and without any possible interaction that can be occurred while teaching listening. Teaching and learning listening did not satisfy her expectations although the participants were not aware of what listening is since most of them held the belief that listening means only listen to the recording and fill in the gaps and do the related exercises and after that finishing it. Learners' beliefs appear to be simplistic and this may be due to their teachers' teaching methodology in teaching listening less communicatively leading to keeping such beliefs about listening. Of course, this issue is discussed in the discussion section completely. The thing to be attended is the participants' lack of understanding of what exactly listening is and what purpose they follow when a listening task is concerned.

\subsubsection{Lack of Interest in Listening}

This category shows that the participants' responses to the questionnaire revealed their reluctance to learn listening skill. It seems that learners' lack of interest in listening lies in the difficulty of the skill they may face as it was highlighted in the previous section. Regarding the lack of interest in learning listening, the majority of the participants $(n=25)$ believed that when they listen to the recording, there are no further activities to make the listening task less boring, and make the learners more interested in listening tasks of the textbook. This belief is shown in the following extract:

\section{Extract 2 .}

"When a listening activity starts, we are asked to listen to the recoding and do the required tasks of the book. It is boring just to answer the questions of the book without having any interaction with the friends or very little interaction with the teacher. This makes it boring for us."

The above extract indicates that participants sought more interaction in listening activity and they were not satisfied with the current method of teaching listening adopted in their classes. Another important point highlighted in their responses was their indifference to listening. More than half of the learners agreed that a listening activity is just to listen and jump to a 
reading or speaking task. It seems that some of the participants appear to be lazy or they wish to pass the time as fast as possible when they are to listen to the recording. In fact, these types of learners may need more justification to be more aware of the purpose of the listening to make them conscious of what exactly listening is and what they are expected to do during listening time. On the other hand, there are some who like more interactive classes while listening exercises start in the classroom and they suffer from less energetic and boring atmosphere.

In the following section, their beliefs after receiving the treatment are presented highlighting its effectiveness in changing their simplistic beliefs about listening.

\subsection{Learners'Beliefs about Listening at the End of the Term}

As to the learners' beliefs at the end of the term, their responses to the questionnaire and interviews highlighted this point that they were satisfied with the treatment in metacognitive listening instruction, and they held positive beliefs about listening. It seemed that metacognitive listening instruction to a large extent brought about some sort of changes in the participants' beliefs about listening. In order to completely analyze the data, it is of value to start with sub-categories of the learners' beliefs about listening at the end of term.

\subsubsection{Listening can be Taken at the Service of Speaking}

Regarding the learners' belief change about listening, all the participants $(n=30)$ who responded to the open-ended questionnaire and participated in semi-structured interview concurred that the new treatment they had received was so effective in that they felt improvement in the listening skill since they were able to listen and simultaneously interact with their peers and the teacher and improve their speaking as well. The extract below shows one learners' positive belief about listening after receiving the treatment:

\section{Extract 3 .}

"With the new method of teaching the teacher had, we could listen and speak about that, and talk to our friends. It was very good and interesting."

It seems that the above learner had a positive impression in terms of teacher's treatment sessions. An interesting point is that she mentioned 'new method of teaching' signaling this fact that it might be for the first time that they had such an interactive class while practicing a listening task and did not experience metacognitive listening. It can also be found that the participants paid a special attention to the role of speaking during the language learning process, and they held positive beliefs about the new approach in teaching listening in that metacognition paved the way for them to freely speak with their friends and teachers about the subject and enjoy the context of interaction taken place as a result of this listening instruction.

\subsubsection{Listening is more Important than other Skills}

In line with the learners' belief change about listening at the end of the term, it seems that metacognitive listening instruction caused the majority of the participants $(n=26)$ to put much more weight on the listening skill in their responses to the questionnaire and interviews as well. They appeared to understand the role listening may play in their success in language 
learning as it helped them to improve their speaking skill highlighted in the previous section. The fact that listening was considered as an important skill, which was held by the participants, values the role of metacognitive listening instruction and the teacher's' abilities to successfully implement this methodological listening treatment in the classroom. As a vivid example, the following extract presents the importance of listening skill:

\section{Extract 4 .}

"I think that listening is more important than speaking and ..... In my opinion, listening can be very important for teaching other skills too. I talk about this based on the listening we had in our class this term."

The fact that they could speak while the focus was on listening created a positive feeling in the learners' mind leading to keep this belief that listening can be more important than other skills of language. With the two sub-categories explained above, it can be easily found that metacognitive listening instruction created a fruitful educational environment for the participants to learn the listening skill in a communicative context resulting in raising a relative awareness in their beliefs about listening at the end of the term.

To sum up, the first research question aimed to find out whether metacognitive listening instruction could change the learners' simplistic beliefs about listening. It was found that almost all the students $(n=28)$, who took part in the interview sessions and answered the questionnaire, seemed to have simplistic beliefs about listening and were not interested in learning listening since it was boring for therm. After receiving the treatment, nearly all the participants in the experimental group changed their beliefs about listening and they put much more emphasis on the role of listening since it assisted them in their speaking practice and made the classroom more interactive, creating an enjoyable environment for listening comprehension, which was the final aim of the instruction. It should be noted that the participants in the control group $(n=15)$, who answered the open-ended questionnaire and took part in the semi-structured interview session, did not change their beliefs at the end of the term. In fact, their beliefs about listening seemed to be simplistic at the beginning similar to the experimental group -, while they did not change their beliefs at the end of the term and repeated their statements about listening as boring or difficult. The findings demand the implementation of metaconitive listening instruction in language classroom paving the way for both teachers and learners to benefit from a communicative context.

To answer the second research question, the results of the pre-and post test were quantitatively analyzed using an independent sample T-test. Hence, in the following, descriptive statistics based on SPSS analysis (version 18.00) are presented.

A descriptive analysis of the results of both the experimental and control group shows a certain development. As Figure 1 shows, the two groups were not that different in terms of their mean on the pre-test. However, the learners in the experimental group performed better than those in the control group on the post-test revealing the positive effect of metacognitive listening instruction on the learners' listening development. 


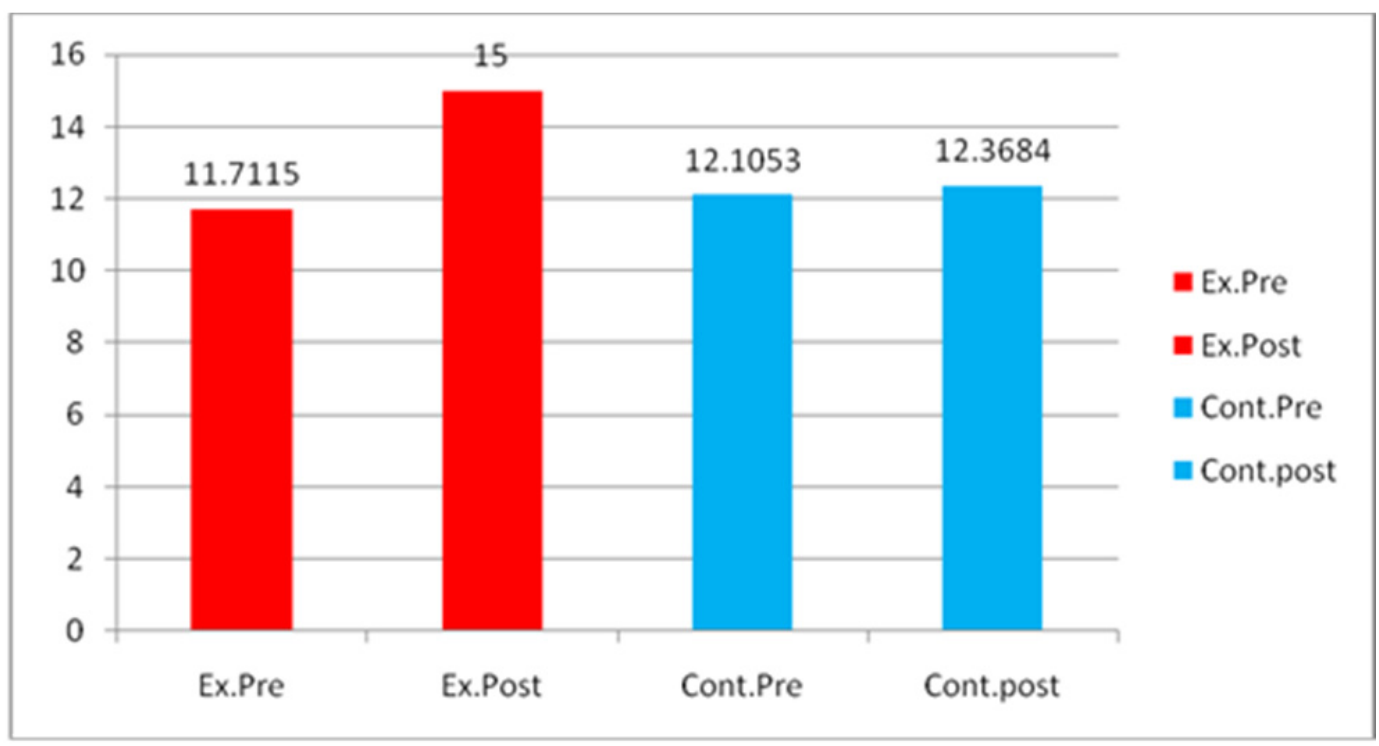

Figure 1. Mean development for experimental and control groups on the pre- and post-test

An independent sample T-test on the learners' performance on the pre-test was conducted to see if learners in the experimental group and the control group differed on their scores on the listening comprehension. For the normality test, the one-sample Kolmogorov-Smirnov results obtained for the pre-test of both groups are .990 and .281 for the experimental group and .795 and 0.553 for the control group respectively, verifying the normality assumption. There was no significant difference for the learners in the experimental group $(\mathrm{M}=11.71, \mathrm{SD}=3.35)$ and the control group $(\mathrm{M}=12.10, \mathrm{SD}=4.04)(t=.48, p=.626, \mathrm{df}=70.62)($ see Table 2$)$.

Table 2. Independent sample t-test for the pre-test

\begin{tabular}{|c|c|c|c|c|c|c|c|c|c|}
\hline & \multicolumn{2}{|c|}{$\begin{array}{c}\text { Levene's Test } \\
\text { for Equality of } \\
\text { Variances }\end{array}$} & \multicolumn{7}{|c|}{ T-test for Equality of Means } \\
\hline & \multirow[t]{2}{*}{$\mathrm{F}$} & \multirow[t]{2}{*}{ Sig. } & \multirow[t]{2}{*}{$\mathrm{t}$} & \multirow[t]{2}{*}{ df } & \multirow[t]{2}{*}{$\begin{array}{c}\text { Sig. } \\
\text { (2-tailed) }\end{array}$} & \multirow[t]{2}{*}{$\begin{array}{c}\text { Mean } \\
\text { Difference }\end{array}$} & \multirow[t]{2}{*}{$\begin{array}{l}\text { Std. Error } \\
\text { Difference }\end{array}$} & \multicolumn{2}{|c|}{$\begin{array}{c}95 \% \text { Confidence } \\
\text { Interval of the } \\
\text { Difference }\end{array}$} \\
\hline & & & & & & & & Lower & Upper \\
\hline $\begin{array}{l}\text { Pre } \\
\text { Equal } \\
\text { variances } \\
\text { assumed }\end{array}$ & 5.023 & .028 & -.504 & 88 & .616 & -.39372 & .78158 & -1.94695 & 1.15950 \\
\hline $\begin{array}{l}\text { Equal } \\
\text { variances } \\
\text { not } \\
\text { assumed }\end{array}$ & & & -.489 & 70.626 & .626 & -.39372 & .80461 & -1.99823 & 1.21078 \\
\hline
\end{tabular}


The same independent sample T-test for the learners' performance on the post-test was carried out to see whether the difference in the learners' performance was significant or not. An examination of the data indicated that there was no violation of the normality assumption. There was a significant difference for the learners in the experimental group $(\mathrm{M}=15, \mathrm{SD}=$ $3.79)$ and the control group $(\mathrm{M}=12.36, \mathrm{SD}=4.23)(t=3.039, p=.003, \mathrm{df}=74.47)$ (see Table 3). The magnitude of the difference in the means was moderate (eta squared $=.094$ ).

Table 3. Independent sample t-test for the post-test

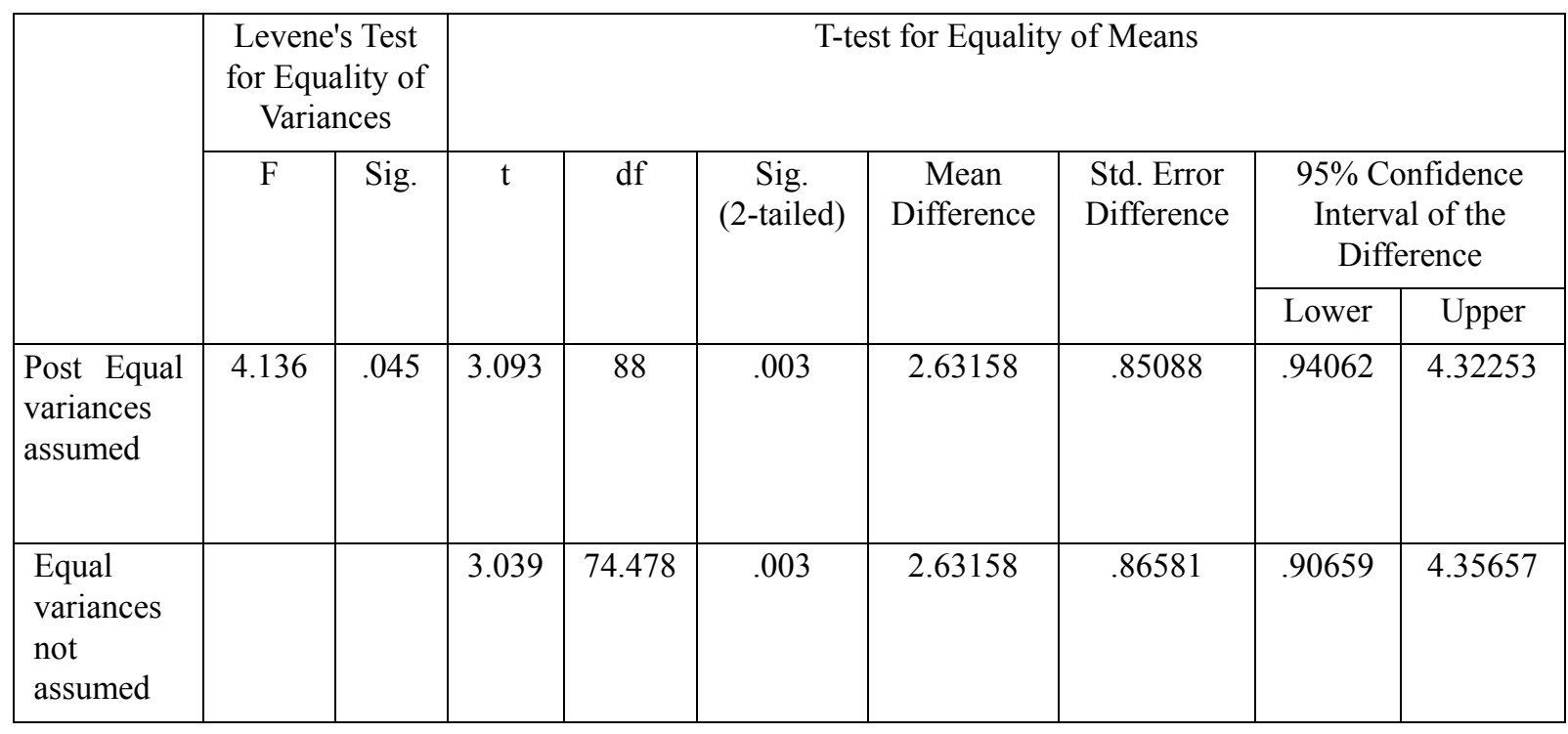

As the Table shows, the experimental group outperformed the control group $(\mathrm{p}<0.05)$, signaling the effectiveness of metacognitive listening instruction. Findings clearly acknowledged the application of listening pedagogical cycle known as metacognitive listening instruction in the classroom, which paves the way for students to improve their listening ability as well as taking part in a communicative environment benefitting from their teacher's support and peer feedback, which led to their final listening development at the end of the term.

In order to answer the third research question, statistical analysis was utilized to quantitatively go for data analysis. Before presenting the findings in terms of the treatment effectiveness for less-skilled listeners, it should be noted that based on the learners' mean on the pre-test (11.71) in the experimental group, it was assumed that those participants who received the grade of 12 or more than this value, were considered as more-skilled listeners while those learners whose listening grade was less than 12 were less-skilled learners (Vandergrift \& Tafaghodtari, 2010). It is of value to note that the listening test (Cambridge Key English Test) consisted of 25 listening tests.

As to the third question, Figures 2 and 3 show that both the less-skilled learners and the more-skilled ones showed some improvement in their performance on the listening comprehension test. 


\section{Macrothink Institute ${ }^{T M}$}

In the less-skilled group, the learners' performance improved greater than that of the learners in the more-skilled group. The mean difference for the less-skilled group from pre-test to post-test was 4.68 (see Figure 2), whereas the mean difference for the more-skilled group was 2.24 (see Figure 3). Apparently, learners in the less-skilled group gained more from metacognitive strategy instruction for listening comprehension. To make sure that the difference was statistically significant, the performance of the groups was compared using one-way between-groups ANOVA.

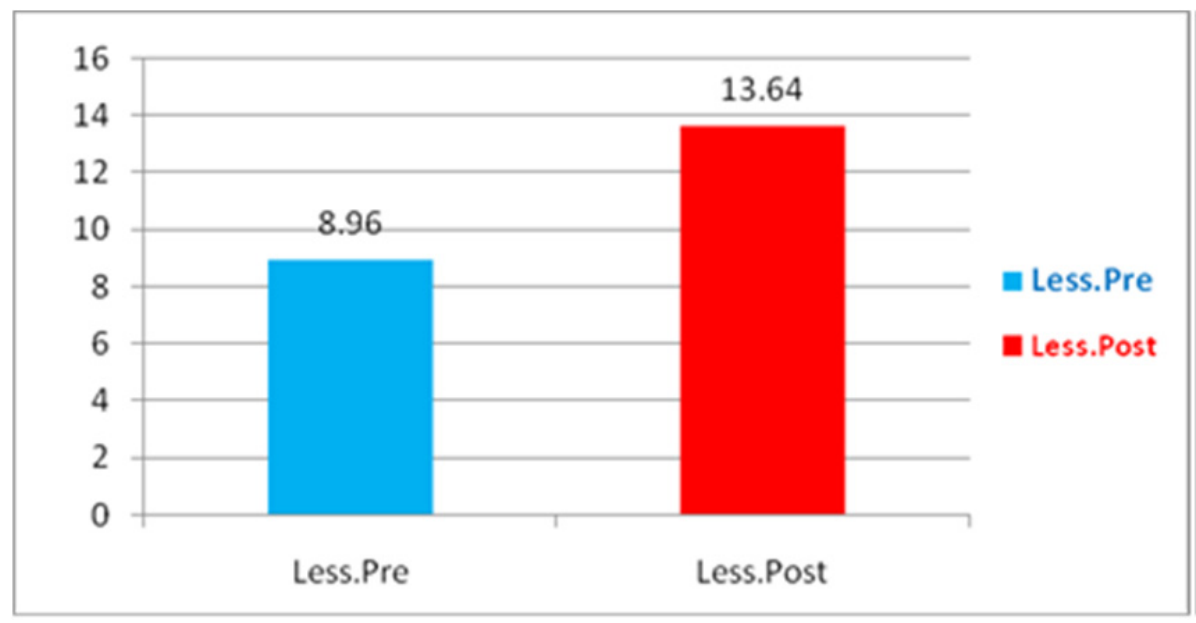

Figure 2. Mean for less-skilled group on the pre- and post-test

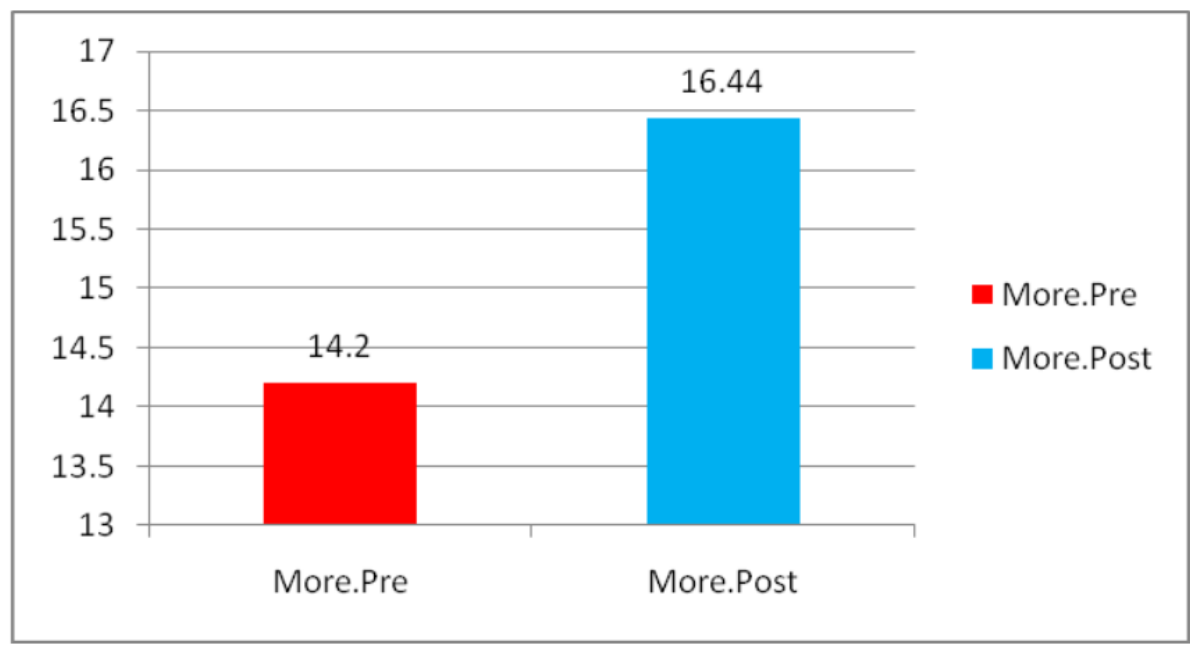

Figure 3. Mean for more-skilled group on the pre- and post-test

A one-way between-groups analysis of variance was conducted to find out the efficacy of the metacognitive listening instruction. There was a statistically significant difference at the $p$ $<.05$ level in the listening scores for the groups $[\mathrm{F} 3,100=28.642, p=.0001]$ (see Table 4). 
Table 5 shows the equality of variance checked by Levene's test for homogeneity The Sig. value of the test of homogeneity of variance is well below 0.05 ; therefore, we looked at the result of the Tamhane's T2 section (see Table 6) since the result shows that the less-skilled group improved significantly on the post-test.

Meanwhile, the comparison of the learners' performance in the less-skilled group in comparison to that of the learners in the more-skilled group showed a significant difference. However, there was no significant difference in learners' performance in the more-skilled group on the pre- and post-test.

Table 4. ANOVA for the less-skilled and more-skilled group on the pre- and post-test

\begin{tabular}{|l|c|c|c|c|c|}
\hline & Sum of Squares & df & Mean Square & F & Sig. \\
\hline Between Groups & 734.746 & 3 & 244.915 & 28.642 & .000 \\
\hline Within Groups & 855.090 & 100 & 8.551 & & \\
\hline Total & 1589.837 & 103 & & & \\
\hline
\end{tabular}

Table 5. Test of homogeneity of variances

\begin{tabular}{|c|c|c|c|}
\hline Levene Statistic & $\mathrm{df1}$ & $\mathrm{df} 2$ & Sig. \\
\hline 5.200 & 3 & 100 & .002 \\
\hline
\end{tabular}

Table 6. Multiple comparisons Tamhane: less-skilled and more-skilled groups

\begin{tabular}{|c|c|c|c|c|c|c|}
\hline \multirow[t]{2}{*}{ (I) Group } & \multirow[t]{2}{*}{ (J) Group } & \multirow{2}{*}{$\begin{array}{c}\text { Mean } \\
\text { Difference (I-J) }\end{array}$} & \multirow{2}{*}{$\begin{array}{l}\text { Std. } \\
\text { Error }\end{array}$} & \multirow[t]{2}{*}{ Sig. } & \multicolumn{2}{|c|}{$95 \%$ Confidence Interval } \\
\hline & & & & & $\begin{array}{l}\text { Lower } \\
\text { Bound }\end{array}$ & $\begin{array}{l}\text { Upper } \\
\text { Bound }\end{array}$ \\
\hline \multirow[t]{3}{*}{ Less-skilledPre } & Less-skilled post & $-4.68000^{*}$ & .75578 & .000 & -6.7912 & -2.5688 \\
\hline & More-skilledPre & $-5.29926^{*}$ & .56046 & .000 & -6.8407 & -3.7578 \\
\hline & $\begin{array}{l}\text { More-skilled } \\
\text { post }\end{array}$ & $-7.29926^{*}$ & .78674 & .000 & -9.4902 & -5.1083 \\
\hline \multirow[t]{3}{*}{ Less-skilled post } & Less-skilledPre & $4.68000^{*}$ & .75578 & .000 & 2.5688 & 6.7912 \\
\hline & More-skilledPre & -.61926 & .82590 & .975 & -2.8979 & 1.6593 \\
\hline & $\begin{array}{l}\text { More-skilled } \\
\text { post }\end{array}$ & -2.61926 & .99346 & .065 & -5.3406 & .1021 \\
\hline \multirow[t]{3}{*}{ More-skilledPre } & Less-skilledPre & $5.29926^{*}$ & .56046 & .000 & 3.7578 & 6.8407 \\
\hline & Less-skilled post & .61926 & .82590 & .975 & -1.6593 & 2.8979 \\
\hline & $\begin{array}{l}\text { More-skilled } \\
\text { post }\end{array}$ & -2.00000 & .85433 & .135 & -4.3527 & .3527 \\
\hline \multirow{3}{*}{$\begin{array}{l}\text { More-skilled } \\
\text { post }\end{array}$} & Less-skilledPre & $7.29926^{*}$ & .78674 & .000 & 5.1083 & 9.4902 \\
\hline & Less-skilled post & 2.61926 & .99346 & .065 & -.1021 & 5.3406 \\
\hline & More-skilledPre & 2.00000 & .85433 & .135 & -.3527 & 4.3527 \\
\hline
\end{tabular}

*. The mean difference is significant at the 0.05 level. 
The analysis of the results in the pre-test and post-test showed that learners in the experimental group improved significantly as a result of receiving the listening strategy instruction. In this regard, the less-skilled listeners seemed to have enjoyed more than the more-skilled listeners since the descriptive analysis shows greater improvement for the former.

To conclude, qualitative analysis highlighted the occurrence of changes in the learners' beliefs about listening at the end of the term after they received metacognitive listening instruction. Similarly, quantitative data analysis of the pre-and post-test indicated that the participants in the experimental group outperformed those of the control group revealing the effectiveness of metacognitive strategy instruction. As to the less-skilled listeners, it was found that they also benefitted from the treatment in comparison to their more-skilled counterparts. It seems that the metacognitive listening instruction can be beneficial for learners who are concerned with learning to listen and improve their listening skill, and particularly less-skilled listeners can gain more in terms of their listening comprehension problems.

\section{Discussion and Conclusion}

As to the first research question, findings highlighted the effective role of metacognitive listening instruction in changing the learners' beliefs about listening. It is to note that almost all the participants in the experimental group were satisfied with the metacognitive treatment and held positive beliefs about listening and changed their simplistic and less-positive beliefs about listening.

Regarding the theoretical framework in terms of belief studies, the present study benefitted from sociocultural theory to justify change in the learners' beliefs during the term. To apply sociocultural terms in the study, experimental group underwent a sort of mediation to change their simplistic beliefs about listening. It seems that the meditational role of metacognitive listening instruction has been so effective leading to change in the learners' beliefs about listening. The factors acting as mediation were the context of interaction in which learners were involved in the communicative context and had a meaningful interaction with their peers and the teacher leading to a successful mediation resulting change in the learners' simplistic beliefs, which clearly highlights the appropriateness of applying sociocultural theory to justify the findings.

In order to interpret the findings in terms of regulation - another practical term in sociocultural theory - it can be found that learners were quite dependent on their teachers and put much more emphasis on the teachers' role when they were to do a listening task at the beginning of the term. But after receiving the treatment through metacognitive listening instruction, they were not afraid of doing the exercises alone and enjoyed solving the listening tasks with their peers and individually. This reveals that the participants of the experimental group benefitted from teacher's support and scaffolding highlighting a change from other-regulation to self-regulation. Therefore, the movement from other-regulation to self-regulation acknowledges the fact that concept from sociocultural theory can be suitably adopted to analyze changes in the learners' beliefs during the life of the course. 
The findings of the study were in line with Alanen (2006) and Yang and Kim's (2011) studies highlighting the role of beliefs as meditational means. They confirmed the suitability of sociocultural theory to investigate learners' beliefs in the process of time. In fact, the above studies verified the application of sociocultural theory to look into beliefs in the context of interaction as proposed by Barcelos (2006).

To address the second research question in terms of the effect of metacognitive listening instruction on the young learners' listening development, findings strongly confirmed the application of a process-based listening approach to facilitate language learning. In order to theoretically discuss the findings, it should be noted that metaconigitve theory of listening highlighted the fact that listening was considered as a process rather than a product. Findings demonstrated that this approach, which stimulates learners to go through a processed-based procedure, can activate the learners' background knowledge and create a better opportunity for students to have an interaction that may lead to internalizing the listening task. The results support the fact that if learners undergo such processes underlying the listening activity, they can surely benefit from this strategy, and metacognitive listening instruction does have merits in this regard. The present study found further empirical support to those of Goh (2002), Goh and Taib (2006), Vandergrift (2004), and Vandergrift and Tafaghodtari (2010), claiming that metaconitive listening instruction as a pedagogical cycle can improve learners' second and foreign language listening skills in the classroom if it is employed in a systematic way and based on the pedagogic needs.

Regarding the effect of metacognitive listening instruction on less-skilled listeners to reach greater improvement (third research question), findings revealed that the pedagogical cycle can be beneficial for listeners with lower levels of listening proficiency in that they may be motivated enough to improve their listening abilities by receiving feedback from more knowledgeable peers or teachers. Results were in line with Vandergrift's and Tafaghodtari's (2010) and Cross's (2010) which highlighted the benefits of metacognitive instruction in listening for less-skilled learners leading to more improvement than more-skilled ones.

In the area of second language listening, research suggests that skilled L2 listeners are able to transfer their L1 listening skills to listening in another language. The good news for less skilled L2 listeners, however, is that they can benefit from metacognitive instruction for L2 listening that raises their awareness about the listening process and teaches effective strategies for managing comprehension and overall listening development. Recent research has demonstrated that this kind of instruction can lead to improved listening ability.

To sum up, sociocultural theory highlighted the notions of regulation and mediation to be a suitable framework in order to justify changes in the learners' beliefs about listening and receiving development in listening ability as a result of metacognitive listening instruction during the term. Cognitive model of listening also supported this fact that learners can benefit from this pedagogical cycle to activate their background knowledge in a listening activity and raise their listening awareness by metacognitive listening treatment, which aims to assist less-skilled learners to gain remarkable development in listening abilities as well.

The present research produced a number of key findings which are summarized below: 
1) As to the learners' responses to open-ended questionnaire and semi-structured interview, it was found that learners' beliefs were found to be probably simplistic at the beginning of the term since they had not experienced the metacognitive listening treatment.

2) At the end of the term, qualitative data clearly highlighted the effect of metagonitive instruction in listening on the learners' belief change about listening in that almost all the participants in the experimental group held positive beliefs about the term and particularly their ability in listening, which was improved, and they were satisfied with the treatment they had underwent.

3) The results of pre- and post-tests indicated that metacognitive listening instruction, to a large extent, led to the learners' development at the end of the term, and their listening development was accompanied by their positive beliefs about listening instruction, which reveals the potential effect of this treatment in pedagogical contexts.

4) As to the quantitative analysis of the learners' pre- and post-tests, it was concluded that metacognitive listening can be beneficial for less-skilled listeners to greatly improve their listening ability as a result of interaction with their peers and the teacher.

5) From sociocultural perspective, the findings confirmed that metacognitive listening instruction acted as a meditational activity leading to change in the learners' beliefs about listening and their listening development. In fact, learners applied the sort of mediation in their learning process to move from other-regulation - learners' dependence on their teacher- to self-regulation - learners' reliance on their own listening abilities and be able to solve the listening tasks individually.

6) Cognition also played an important role in terms of activating learners' prior and background knowledge while doing a listening activity, which may result in their awareness raising of the listening skill, and finally learners can reach improvement in their listening performance when they receive metacognitive listening instruction.

\section{Practical Implications and Suggestions for Future Research}

The findings of the study suggest some productive and practical implications in terms of the educational system adopted in teaching and learning listening in a foreign language context such as Iran. The main practical implications include:

1) Metacognitive listening instruction should be recognized as an appropriate procedure to teach listening in language institutes and schools, which seems to be beneficial for both learners and teachers.

2) Findings suggest that metacognitive listening instruction can raise the learners' awareness regarding their probable simplistic beliefs at the beginning of the term and change them to more realistic beliefs about listening, probably resulting in consciously acquiring listening skill and being motivated enough toward listening. 
3) In order to teach listening efficiently, it would be better for teachers to be aware of the learners' beliefs about listening at the beginning of the term, and make their best attempt to change those unrealistic beliefs about listening on the way of learning to listening, and this goal seems to be achieved by metacognitive listening instruction.

4) To raise teachers' awareness of meacognitive listening instruction, teacher education program should be scheduled for both novice and expert teachers to upgrade their knowledge of teaching listening and reach consensus in terms of the suitability of applying this treatment in the classrooms.

5) The effectiveness of metacognitive instruction has been approved in listening skill. It is of value to take its practical application into account in terms of other language skills, which demands more elaboration and reflection to show whether it can be implemented in other main language skills to pave the way for both teachers and learners to teach as communicatively as possible, which seems to be the main concern for all teachers in recent years.

Regarding suggestions for future studies, it is significant to sketch the limitations underlying the current study and then go through the recommendations for further research in metacognitive listening instruction. limitations of the study demand consideration:

First, the present study doesn't concentrate on adult learners to find the sort of probable relationship between their listening development and young learners in terms of receiving the metacognitive instruction. Future research can be conducted to seek how differently young and adult learners react to metacognitive instruction.

Second, this study benefits from quantitative methodology to analyze the effectiveness of metacognitive instruction on listening development. It would be interesting to analyze teachers and students' talk while engaged in listening instruction in the classroom. In this way, the precise details of metacognitive instruction can be achieved qualitatively. In fact, here, it is aimed to apply conversation analysis (CA) perspective to interpretatively go for the classroom talk to elaborate on the undeniable effect of metacognitive listening instruction.

Third, the present study may not consider teacher's beliefs about listening to find out the sort of relationship which may exist between their perceptions leading to better teaching. To gain better results in terms of belief systems, learners and teachers' beliefs should be investigated to improve those unrealistic beliefs held by both teachers and learners. If teachers' beliefs are found to be unrealistic about listening, teacher education program should be planned to raise teachers' awareness of metacognitive listening instruction. Hence, teachers can give insights to their students resulting in their awareness as well, which can be beneficial for both parties to enjoy the classroom atmosphere.

\section{References}

Alanen, R. (2006). A sociocultural approach to young language learners' beliefs about language learning. In P. Kalaja, \& A. M. F. Barcelos (Eds.), Beliefs about SLA: New research approaches (pp. 55 - 86). Netherlands: Kluwer. 
Barcelos, A. M. F. (2006) Researching beliefs about SLA: A critical review. In P. Kalaja \& A. M. F. Barcelos (Eds.), Beliefs about SLA: New research approaches (pp. 7-33). Netherlands: Kluwer.

Bernat, E. (2008). Beyond beliefs: Psycho-cognitive, sociocultural and emergent ecological approaches to learner perceptions in foreign language acquisition. The Asian EFL Journal, 10, 7-27.

Birjandi, P., \& Rahimi, A. H. (2012). The effect of metacognitive strategy instruction on the listening performance of EFL students. International Journal of Linguistics, 4, 495-517. http://dx.doi.org/10.5296/ijl.v4i2.1707

Cross, J. D. (2010). Metacognitive instruction for helping less-skilled listeners. ELT Journal, 65, 408-416. http://dx.doi.org/10.1093/elt/ccq073

Elkhafaifi, H. (2005). Listening comprehension and anxiety in the Arabic language classroom. The Modern Language Journal, 89, 206-220. http://dx.doi.org/10.1111/j.1540-4781.2005. 00275.x

Dornyei, Z. (2007). Research methods in applied linguistics. Oxford: Oxford University Press.

Glaser, B. G., \& Strauss. A. (1967). The discovery of grounded theory: Strategies for qualitative research. Chicago: Aldine.

Goh, C. (2002). Exploring listening comprehension tactics and their interaction patters. System, 30, 185 - 206. http://dx.doi.org/10.1016/S0346-251X(02)00004-0

Goh, C., \& Taib, Y. (2006). Metacognitive instruction in listening for young learners. ELT Journal, 60, 222- 232. http://dx.doi.org/10.1093/elt/cc1002

Horwitz, E. (1988). The beliefs about language learning of beginning university foreign language students. Modern Language Journal, 72, 283-294. http://dx.doi.org/10.2307/327506

Kern, R. G. (1995). Students' and teachers' beliefs about language learning. Foreign Language Annals, 28, 71-92. http://dx.doi.org/10.1111/j.1944-9720.1995.tb00770.x

Lantolf, J. P. (2004). Sociocultural theory and second and foreign language learning: An overview of sociocultural theory. In K. van Esch \& O. St. John (Eds), New insights into foreign language learning and teaching. Frankfurt am Main: Peter Lang.

Lantolf, J. P., \& Thorne, S. L. (2006). Sociocultural theory and the genesis of second language development. Oxford: Oxford University Press.

Mackey, A., \& Gass, S. (2005). Second language research, methodology and design. Mahwah, N.J.: Lawrence Erlbaum.

Rasouli, M., Mollakhan, K., \& Karbalaei, A. (2013). The effect of metacognitive listening strategy training on listening comprehension in Iranian EFL context. European Online Journal of Natural and Social Sciences, 2, 115-128.

Vandergrift, L. (2004). Learning to listen or listening to learn? Annual Review of Applied 
Linguistics, 24, 3-25. http://dx.doi.org/10.1017/S0267190504000017

Vandergrift, L. (2007). Recent developments in second and foreign language listening comprehension research. Language Teaching, 40, 191-210. http://dx.doi.org/10.1017/S02614 44807004338

Vandergrift, L., \& Tafaghodtari, M. H. (2010). Teaching students how to listen does make a difference: An empirical study. Language Learning, 60, 470-97.

Yang, J-S. \& Kim, T-Y. (2011). Sociocultural analysis of second language learner beliefs: A qualitative case study of two study-abroad ESL learners. System, 39, 325-334. http://dx.doi.org/10.1016/j.system.2011.07.005 


\section{Appendix}

Appendix 1. Cambridge Key English Test of Listening
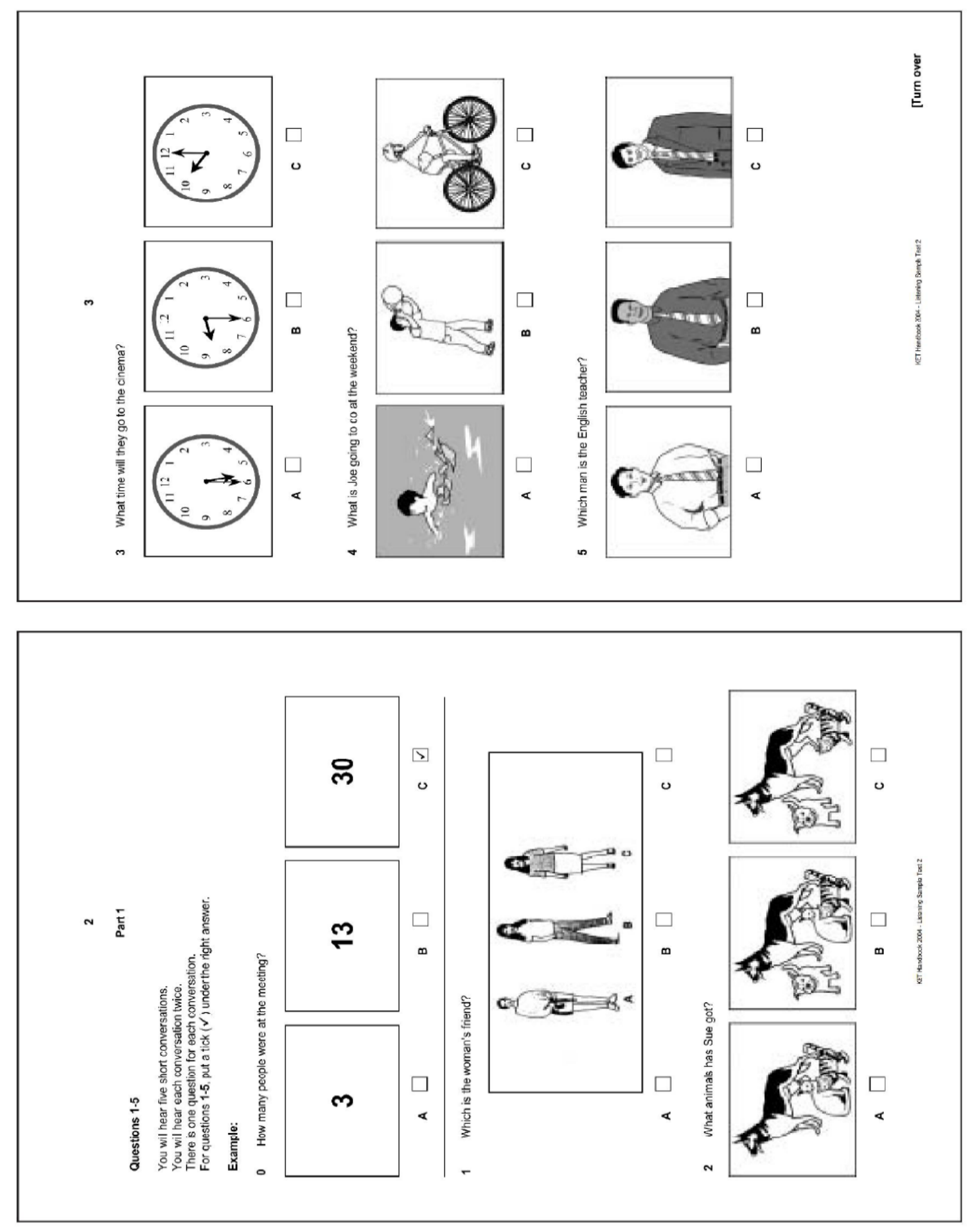

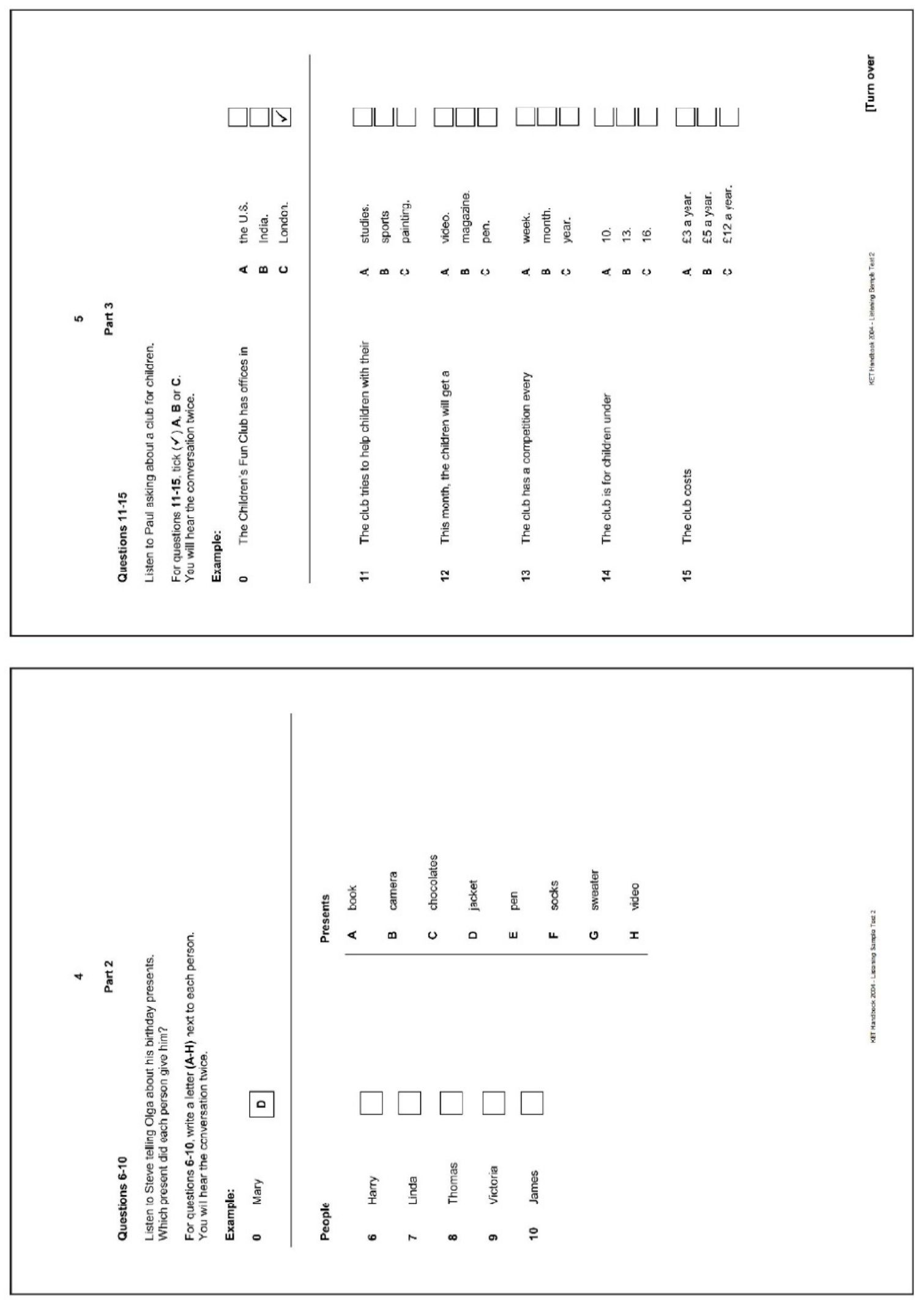

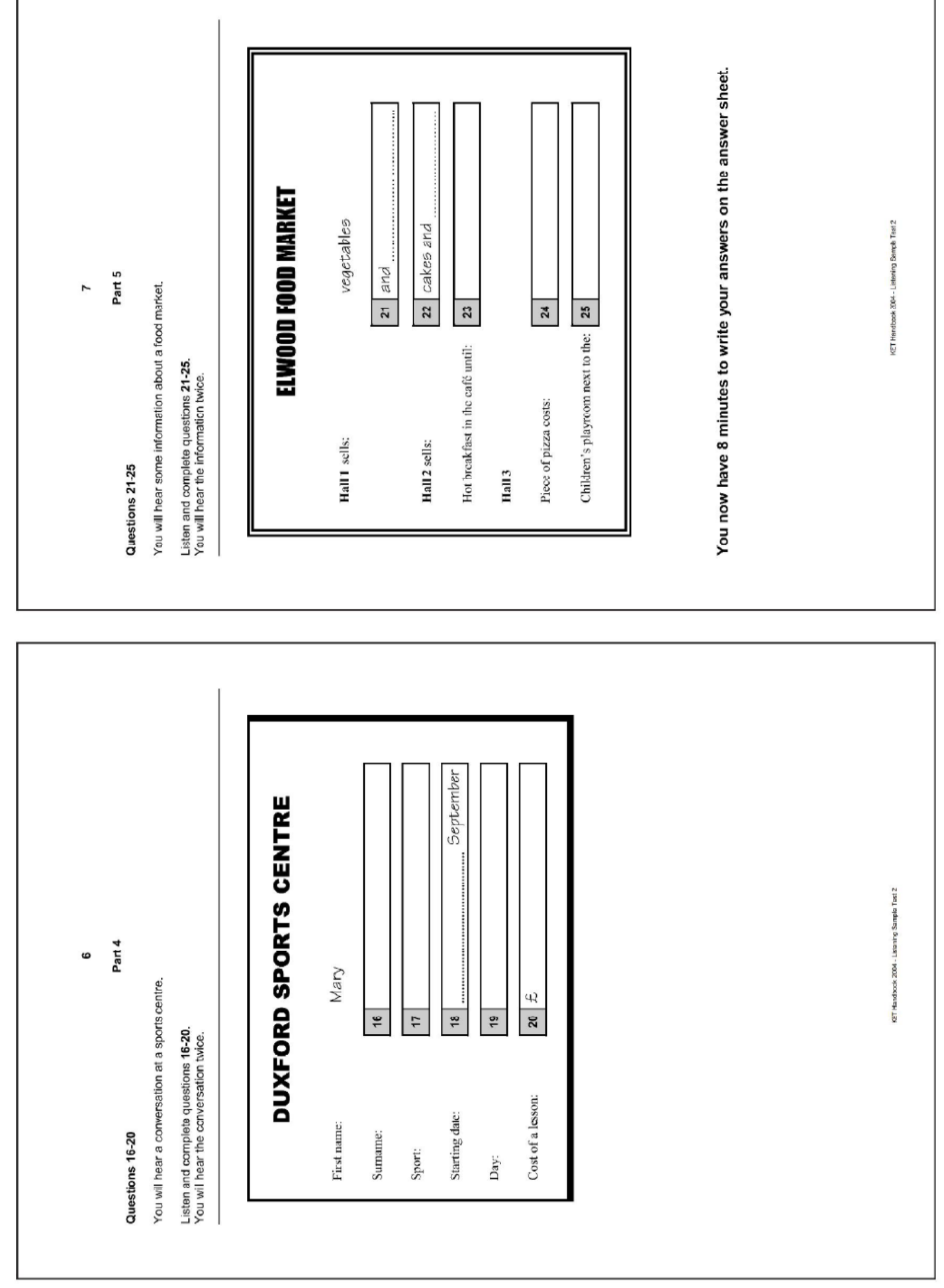

\section{Copyright Disclaimer}

Copyright reserved by the author(s).

This article is an open-access article distributed under the terms and conditions of the Creative Commons Attribution license (http://creativecommons.org/licenses/by/3.0/). 